\title{
TAFSIR SEMANTIK TERHADAP SURAT AL-KAFIRUN
}

\author{
Imam Muslimin
}

Dosen Jurusan Bahasa dan Sastra Arab, Pembantu Dekan Bidang Kemahasiswaan

Fakultas Humaniora dan Budaya, Universitas Islam Negeri (UIN) Malang.

Jalan Gajayana No. 50 Telepon (0341) 570872, Faksimile (0341) 570872 Malang 65144

\begin{abstract}
The problems about the reading of al-Qur'an is always interesting to be discussed, in which the use of Arabic includes sound or 'nash' is acrucial factor to understand the implicit meaning of the Arabic-written texts. Al-Qur'an discusses problem based on the society's culture. Al-Kafirun discusses not only about the normative theology but more about sociological contexts in which it tends to show transparency, fight against fanaticism and regionalism. And all of the will bring to the first process of the making of the text meaning to the situational context that creates them.
\end{abstract}

Key words

Al-Kafirun, Semantic, Tafsir, Meaning

\section{Pendahuluan}

Wacana umum yang sering kita dengar dan kita saksikan di kalangan khalayak, termasuk di kalangan para pemikir kontemporer di dunia Islam adalah persoalan pembacaan teks wahyu, hal ini menyangkut eksistensinya yang begitu kental dengan idiologi-idiologi Arab setempat yang menempatkannya pada level qur'ani, artinya ada satu korelasi logis, ketika wahyu ini diturunkan di dunia Arab apalagi menggunakan bahasa setempat akan ikut memberikan warna atau corak 
teks wahyu dalam segala segi, misalkan corak logika, peta pemikiran, tradisi, budaya dan tatanan sosial lainnya, hingga sulit memastikan antara suruhan Ilahi atau itu memang tradisi budaya mereka sendiri (Arabic culture), statemen ini sudah jelas ditemukan dalam al-Qur'an dalam firman-Nya sebagai berikut: "Lisanun Arabiyyun Mubin", artinya: Bahwa bahasa al-Qur'an menggunakan bahasa Arab yang nyata (QS. AlNahl: 103).

Ayat di atas, masih mengandung bias secara makna. Artinya sipengguna bahasa dengan bahasa yang digunakan terdapat kesepakatan, sebab bahasa merupakan hasil penyimbolan yang dilakukan oleh si pengguna bahasa secara sadar dengan lingkungannya. Ada yang mengatakan bahwa bahasa adalah teks dan teks itu adalah bahasa itu sendiri, kesimpulan ini dilontarkan oleh kalangan linguis barat semisal Ferdinand De Saussure, yang mengatakan: "Bahwa bahasa merupakan tanda atau simbol", dan Ia menganggap teks sama dengan bahasa yang menyimpan makna-makna dan tanda-tanda, disini tidak dibedakan antara bahasa biasa seperti bahasa manusia, atau bahasa transendental seperti bahasa teks wahyu, semua ini berlaku pada keseluruhan bahasa tanpa kecuali. Ia memberikan penjelasan tentang tanda dalam hubungan manusia dengan manusia lain atau manusia dengan apapun yang ada dalam genggaman manusia dengan cara memebedakan antara penanda dengan petanda atau signified dengan signifiant. Penanda adalah aspek material bahasa atau suara yang menghasilkan makna sedangkan petanda adalah aspek mental bahasa yakni konsep atau pemaknaan dari sebuah bahasa (Kurniawan, 2001:13-14).

Dengan demikian, dibutuhkan pembacaan ekstra hati-hati untuk dapat memahami secara detail kerangka pikir al-Qur'an, sedangkan pembacaan, penafsiran dan atau penakwilan dilakukan bukan saja karena ia adalah bahasa yang diturunkan dibumi Arab atau di dunia episteme tertentu melainkan ia juga merupakan produk budaya yang merupakan hasil dialektika teks wahyu dengan realitas masyarakat Arab yang ada. 
Lewat asumsi seperti itu, pembacaan ini mendapatkan signifikasinya sebagai sebuah upaya untuk mengembalikan al-qur'an kepada titah awal yang tidak dipahami secara ngawur, melainkan harus dipahami secara konteks situasional, hinggga menemukan ruh dari maksud dan tujuan sebenarnya dari teks wahyu tersebut, sebagai dampaknya adalah si pembaca mudah mengarahkan makna awal kepada makna sekunder yang cocok dengan tuntutan zaman dengan kata lain, cocok di setiap tempat dan setiap zaman. Inilah yang dimaksud dengan al-qur'an mengikuti perkembangan realitas tetapi realitas tidak mengikuti al-qur'an, Sebab teks wahyu terbatas, turun dalam kurun waktu yang sangat terbatas pula, sedangkan realitas tidak terbatas terus menerus berkembang, tidak stagnan.

\section{Pembacaan Teks terhadap Wahyu}

Pembacaan terhadap teks wahyu dilakukan karena bahasabahasa yang digunakan banyak mengandung kalimat-kalimat yang sepadan (musytarak) atau dalam bahasa indonesia dikenal dengan sebutan polisemi, kalimat majaz, metafora, perumpamaan, dan bahasa al-Qur'an merupakan bahasa yang sangat luas, mendalam dan tidak terbatas pada satu makna atau satu tunjukan (Harb, 2003:40).

Di samping berisi ayat-ayat mutsyabihat juga berisi ayat-ayat muhkamat, maka nalar Arab Islam harus mampu mencarikan solusi terhadap fenomena-fenomena krusial seperti ini, terlebih lagi, untuk para pembaca non Arab, seharusnyalah untuk berusaha sekuat tenaga untuk dapat memahami sesuai dengan keberadaan dan tujuan yang diinginkan oleh teks wahyu itu sendiri, bahkan hal itu menjadi satu kewajiban setiap muslim untuk berusaha memahami dan mengetahui, secara khusus mengetahui keinginan teks dengan segenap pengetahuan yang ada. Jika ahli balagah menyusun konsep majaz untuk mengungkapkan kekhasan bayan al-Qur'an, maka ahli (teologi) menciptakan konsep takwil untuk menghilangkan kontradiksi antara teks dan nalar. Sebab, selama bahasa teks bersifat metaforis, yaitu menggunakan bahasa tidak sebagaimana aslinya, maka takwil 
(penafsiran) harus mengembalikan signifikansi yang hilang, atau kita harus pindah dari satu signifikansi kesignifikansi yang lainnya (Harb, 2003:40).

Ide dasar dari pendapat-pendapat ini adalah kalam wahyu (AlQur'an) adalah teks paling unggul (aula an-nushush), ia adalah kalam yang paling fasih, paling ringkas, paling banyak simbolnya dan paling banyak maknanya dan khas dengan takwil. Maksudnya, tidak mengutamakan satu makna atas makna lainnya dan memenangkan satu signifikansi atas signifikansi lainnya, dan tidak semata merupakan perbedaan dan perpisahan, perbedaan pandangan dan pemisahan keinginan (hawa nafsu) yang menyebabkan perpecahan umat dan kelompoknya.

Tetapi secara umum, teks bayan ibarat lubang-lubang yang dari dan padanya signifikansi mengalir (masuk) sebagaimana kata Roland Barthes (1982:62-63), di mana ucapan menjadi "ensiklopedi" yang memuat semua definisi, cahaya yang meyorotkan sinarnya menuju seluruh relasi yang mungkin, dan symbol yang berubah menjadi sejarah dan esensi. Sebagai konsekwensinya adalah ditemukan pluralitas dan perbedaan esensi, waktu dan wacana.

Sedangkan jika Al-Qur'an adalah mukjizat bayan (Harb, 2003:42), maka tidaklah jauh dari realitas jika kita katakan bahwa $i^{\prime} j a z$ adalah potensi yang tak lekang dari takwil (pembacaan ulang), i'jaz bayani bukan sebagai signifikansi final yang hanya terungkap sekali untuk selamanya.

Pada prinsipnya, pembacaan tidak berhenti dengan berhentinya teks, apaplagi teks wahyu yang telah lama berhenti turun semenjak lima belas abad silam, ini bukan berarti putus dari pemaknaan dan proses pembacaan, bahkan terus menerus membutuhkan pembacaan secara intensif yang melampaui tempat dan waktu sesuai dengan kondisi ataupun situasi dimana tempat ia actual, dan bahkan butuh pembacaan mendalam dengan mengerahkan segenap pengetahuan yang dimiliki tanpa batas dan tanpa berhenti berinovasi. 
Teks hendaknya menjadi wilayah kajian atau pemikiran, ini menandakan bahwa teks membutuhkan sebuah pembacaan yang mengubah dirinya dari sekadar kemungkinan menjadi proses pengetahuan yang produktif. Oleh karena itu, syarat pembacaan (Harb; 2003:20) dan alasan keberadaannya, semestinya berbeda dengan teks yang dibaca, dan hendaknya pembacaan itu menyingkap apa yang tidak dan belum ditemukan sebelumnya. Adapun model pembacaan yang menyoal apa yang diucapkan seorang pengarang maka pada dasarnya ia tidak menjastifikasi asal (al-ashl). Karena asal adalah lebih utama dibanding dengan pembacaan, oleh karenanya tidak membutuhkan pembacaan, tetapi jika pembacaan itu, secara mendasar, mengakui bahwa dirinya membicarakan apa yang tidak diungkapkan oleh seorang pengarang, maka dalam hal ini, pembacaan tidak membutuhkan teks dan bahkan ia menjadi lebih utama dibanding teks. Demikianlah model pembacaan yang menyia-nyiakan teks dan yang berlawanan dengan model pembcaan yang menyia-nyiakan dirinya sendiri, pembacaan yang seperti ini sama dengan tidak membaca atau pembacaan yang tergolong sia-sia.

Adapun pembacaan yang hidup adalah usaha pembacaan terhadap esensi teks yang berbeda sebagaimana, pada saat yang sama, teks tersebut berbeda dengan dirinya sendiri. Ia adalah pembacaan yang aktif produktif (Harb, 2003:21) terhadap berbagai teks. Perbedaan bukan berarti aib atau berlawanan, sebaliknya, ia merupakan kemungkinan dan kekuatan.

Pembacaan yang baik bukan berarti pembacaan yang memperbincangkan apa yang dibahas oleh teks, melainkan membuka apa yang yang tidak disentuh dan yang dilupakan oleh teks. Yakni, pembacaan itu tidak menafsirkan maksud yang diinginkan, tetapi membuka sesuatu yang dihalangi dalam ucapan. Oleh karena itu, pembacaan seperti ini tidak memberlakukan teks sebagai wacana yang jelas dan sejenis "khitab muhkan mutajanis" (Harb; 2003:22), tetapi sebagai sebuah kerancuan, yaitu teks yang beragam dan semu, yang berbeda dengan dirinya sendiri sebagaimana perbedaan pembacaan 
terhadap teks, semisal pembacaan Ibnu Arabi terhadap teks nabawi, dan pergumulannya dengan teks tersebut.

Ini adalah persoalan teks yang urgen dan atsar yang agung, semua menuntut pada pembacaan produktif yang melampaui segala yang tertulis dalam teks. Secara lebih khusus, sebuah pembacaan diorientasikan untuk membaca teks-teks dan melakukan ekperimentasiekperimentasi untuk menembus hal-hal yang masih ambigu, hal-hal yang bersifat mungkin, yaitu pembacaan yang tidak hanya membaca yang sudah diketahui saja untuk menelangjangkan dan untuk menilainya, akan tetapi untuk menjelaskan secara detail segala yang yang majhul, gaib dan jauh dengan asumsi bahwa teks dianggap sebagai sesuatu yang sangat mungkin untuk diteliti dan dikoleksi. Jadi, praksisnya, siapapun yang membaca teks, baik dalam bentuk teks qashidah, cerita atau dalam bentuk teks falsafat, secara pasti, jangan sampai pembacaannya hanya sekadar mengetahui nilai-nilai historisnya atau hanya untuk mengungkap realitas dan masa berlakunya saja. Tetapi haruslah bagi seorang pembaca membaca dengan pembacaan aktif produktif, kemudian berusaha menerobos segala kemungkinankemungkinan dengan mengungkap segala sekat-sekat kelas dan mengeluarkan isi dan atau berusaha menampakkkan penjelasan dalam teks tersebut.

Demikianlah, pembacaan yang harus ditempuh dalam pembacaan sebuah teks, hatta teks wahyu, sehingga seorang pembaca bukan sekadar membaca dengan pembacaan yang dogmatis dan semata pembacaan yang ilmiah-epistemologis, artinya bahwa pembacaan bukan bersifat linier, dimana si pembaca hanya melihat kebenaran ideide dan ayat-ayat dan hanya mendukung kevalidan wahyu saja, disamping memang harus kita berusaha -memang- untuk memperlihatkan kebohongannya, oleh karenanya, ketika membaca wacana kenabian, ini berarti tidak berinteraksi secara datar, yang mana hanya mengungkap makna yang menunjuk kepada satu peristiwa saja, akan tetapi juga dari dimensi realitas itu sendiri, artinya bahwa keberadaan teks kenabian itu sendiri seperti relaitas teks-teks kebahasaan yang lain yang membebani dirinya kepada kita. 


\section{Kerangka Teori dalam Analisis Teks}

Teori yang digunakan dalam analisis teks nabawi (al-Qur'an) dalam hal ini adalah teori semantik yang fokus pada teori konteks situasional, yang mana teori ini adalah bagian organik dalam studi makna (semantic studies).

Konteks adalah posisi atau keberadaan sesuatu dan proses, seperti dikatakan, bahwa ungkapan ini dalam konteks ucapan ini, artinya berada bersamaan dengan keseluruhan teks, jadi, jika memahami atau menakwilkan sesuatu, maka harus melihat konteks kejadiannya dimana, pada saat apa dan bagaimana sesuatu itu berlansung (Saliba, 1994:681).

Menurut Geoffery Leech, ada beberapa kemajemukan makna dalam konteks (Leech, 2003:100-101), sehingga sangat dibutuhkan konteks tertentu untuk memahami segala sesuatu, baik konteks kebahasaan maupun konteks non kebahasaan, kemajemukan atau kekhususan makna tersebut dapat dilihat karena posisinya sebagai berikut:

Pertama, Konteks dapat menghilangkan ketaksaan makna tertentu atau dapat menghilangkan dualisme makna dalam satu pesan, misalkan, kita harus mengetahui secara benar bahwa kata page pada saat tertentu dapat bermakna anak seorang penjaga, bukan bagian dari kertas.

Kedua, Konteks dapat mengarahkan kepada sumber dari jenis suatu kata tertentu, yang kita sebut dengan deitic seperti, ini, itu, disini, disana, sekarang dan sebagainya. Dan dapat mengetahui suatu ekspresi yang lain dari makna yang sebenarnya, seperti kata saya, kalian, dia, seorang lelaki dan sebagainya.

Ketiga, Teks juga dapat memberikan imformasi atau berita, yang mana bagi si pembicara atau si penulis menghilangkannya dengan cara membuang kalimat sebelumnya atau dengan cara mempersingkat kata, misalkan kita memanggil Zaid tetapi tidak mengatakan sesuatu apapun kepadanya kecuali hanya berupa pangggilan saja, sedangkan dia 
mengetahui makna panggilan tersebut dari konteks, bahwa panggilan itu dimaksudkan untuk membuka jendela misalkan, tetapi kalimat sebelumnya dibuang karena sudah dimaklumi.

Konteks merupakan pasar untuk mengetahui makna secara mendetail, tidak membedakan antara konteks dalam bentuk kebahasaan mapun konteks yang berada dalam eksistensi non kebahasaan, Fierth melukiskan bahwa makna sesungguhnya hanya dapat diungkap melalui pengkontektualisasian unit-unit bahasa, artinya memposisikannya dalam berbagai konteks yang berbeda, tanpa ada dikotomi konteks. (Umar, 1982:21).

Konteks peristiwa artinya proses berlansungnya sebuah peristiwa, keterkaitan, relasinya antara satu dengan yang lainnya, jadi apabila ada satu peristiwa bersamaan dengan kondisi yang melingkupinya, itulah yang disebut sebagai realitas kejadian dalam konteksnya, dan apabila berlawanan dengan keberadaan waktu atau kondisi yang ada maka harus mencari peneyebab dari keberlawaanan ini, seperti misalkan konteks sakit, konteks gejala-gejala kejiwaaan, dan atau fenomena social (Saliba, 1994:681).

Oleh karenanya, studi terhadap makna-makna kata menuntut adanya beberapa konteks atau posisi-posisi yang ada dalamnya, sekalipun itu menyangkut sesuatu yang berasal dari non kebahasaan, dengan demikian makna kata-kata tergantung atau mengikuti pluralitas konteks yang ada.

Jelaslah bahwa konteks sangat membutuhkan keberadaan atau posisi sesuatu untuk dapat mengetahui maknanya, oleh sebab itu makna harus dilihat dalam setiap konteksnya yang ada, dapat dirumuskan sebagai berikut:

\section{(Makna = konteks adalah sesuatu yang dapat disaksikan)}

Karena terkadang bahasa tidak berhubungan lansung dengan realitas sebagaimana realitas juga tidak berhubungan lansung dengan bahasa, maka, dalam praktiknya sebagian para ahli linguistik semisal 
Blomfeld mengatakan: "Bahwa makna mengikuti bentuk sederhana dari sebuah konteks", dimana hubungan antara konteks dan makna tidak secara lansung (Leech, 2003:97). Hal ini dapat dirumuskan sebagai berikut:

\section{(Makna = Sesuatu yang dapat diperoleh dari konteks yang ada) \\ (Makna = Sesuatu yang dapat direduksi menjadi konteks yang ada)}

Tampak dari sini semuanya, bahwa makna dapat diperoleh lewat pengulangan konteks, atau dapat dikatakan bahwa keberadaan makna karena keberadaan konteks, sedangkan makna sangat membutuhkan posisi atau tempat untuk dapat dipahami dengan sebenar-benarnya dan sejelas-jelasnya. Walaupun belum tentu konteks tidak mesti membawa kepada makna yang sempurna.

\section{Mauqif (Situasional Contex)}

Pendekatan kontektual yang dimotori oleh Fierts sendiri mengatakan bahwa makna sebuah kata dapat diketahui lewat penggunaannya dalam bahasa atau metode yang digunakan, atau dapat dilihat dalam peran yang dimainkannnya (Umar, 1982:56). Misalkan, pendekatan konteks situasional harus mengetahui kondisi dimana penggunaan satu kata dalam konteks situasi eksternal seperti penggunaan kata yarham pada saat mendengar orang bersin dari kalimat yahamukallah, artinya mendoakannya dalam rangka mengharap rahmat kesehatan di dunia bukan untuk negeri akhirat, berbeda dengan kalimat Allahu yarhamuh yang konteknya untuk orang yang sudah meninggal dunia yang mana artinya adalah memintakan rahmat untuk negeri akhirat.

Pendekatan konteks mauqif (situasional contex) digunakan karena sangat singkron dengan penelitian ini, dimana penelitian ini ingin menggali makna surat al-Kafirun dengan segenap keberadaan teks dengan realitas yang sedang berkembang pada saat itu. 


\section{Mauqif disini dapat diartikan sebagai berikut;}

Pertama, Posisi atau keberadaan manusia atau hewan secara objektif, dan sering dimutlakkan dengan eksistensi dan mengukurnya kepada keberadaan realitas yang ada.

Kedua, Dalam kajian psikologi atau kajian ilmu-ilmu social mauqif (konteks situasional) diartikan sebagai penempatan makhluk hidup atau wujud person yang dilihat dari segi interaksinya dalam satu dari beberapa kurun waktu beserta lingkungan sosial, lingkungan alam dan model pemikirannya.

Ketiga, Standar mauqif (konteks situasional) ini sendiri adalah standar yang diambil berdasarkan ikatan yang diambil dari premispremis realitas yang ada, khususnya dalam kejadian yang bersifat parsial, tidak terikat dengan ketentuan undang-undang dan prinsipprinsip tata nilai secara umum. (Saliba, 1994:450)

Oleh karenanya sangat beralasan jikalau penulis menjadikan konteks ini sebagai dasar pisau analisis pembacaannya terhadap surat al-Kafirun, dengan melihat situasi yang berkembang waktu itu secara khusus, tidak melihatnya secara general, artinya melihat interaksi pembaca (tempat diturunkannya wahyu, sebuah kajian hermeneutik) tidak melibatkan wilayah eksternal sosial masyarakat Arab.

Memahami teks tidak hanya didukung oleh konteks yang ada namun juga didukung oleh keberadaan pembaca pada saat membaca sebuah teks, artinya membaca bukan sekadar membaca yang hanya mengulangi bentuk kata-kata tanpa mau menafsirkan atau menakwilkan teks yang dibaca, tetapi membaca disini atau kita sering menyebutnya sebagai sebuah proses pembacaan merupakan sebuah proses membaca sekaligus menafsirkan, menakwilkan atau menjelaskan (Syahrur, 1990: 93-94), seperti ungkapan anda kepada saudaramu bacalah kitab ini, artinya jelaskanlah kitab ini.

Menurut Hasan Hanafi, bahwa membaca sebuah teks sama dengan proses memahaminya, sedangkan alat untuk memahami adalah logika bahasa, orientasi teks atau konteks mauqif-nya (situasional contex) dan semangat zamannya, hal inilah yang akan mampu menunujukkan 
kita kepada proses penakwilan. artinya sebuah pembacaan adalah sebuah proses rekonstruksi makna dalam persepsi si pembaca (Saenong, 2002:125). Sedangkan menurut Ali Harb pembacaan soyogyanya harus mensyaratkan makna baru, tidak dikatakan membaca kalau tidak memberikan makna baru pada sebuah pembacaaan.

Dengan demikian pembacaan merupakan pendukung teori dalam memahami teks dengan cara menafsirkan dan menakwilkan teks sesuai dengan konteks situasionalnya.

Corak pembacaan -dalam hal ini- adalah pembacaan yang bersifat indefenden (bebas), dalam artian pembacaan terhadap teks, tidak saja dapat dimulai dari awal surat namun dapat dimulai dari akhir surat, dengan satu asumsi, bahwa surat ini merupakan satu kesatuan struktur dan tidak terpisah-pisah, tidak dibatasi oleh ayat lain atau bukan bagian dari ayat lain, sehingga logika bahasanya dapat dianggap sistematis.

\section{Membaca Surat al-Kafirun: Perspektif Semantik}

Sebelum mcnerawang lebih jauh dapat di sini diungkapkan makna secara umum dari surat al-Kafirun bahwa surat ini adalah surat yang menginformasikan tentang system yang ada di dunia Arab khususnya, baik system yang telah lama berkembang maupun system yang baru datang, yaitu imformasi tentang keberadaan kedua system yang saling berdialektik satu dengan lainnya, dengan membawa idiologi-idiologi masing-masing. Tidak seperti anggapan para ulama' tafsir konvensional bahwa surat ini adalah semata termasuk surat tauhid, artinya surat yang mengandung perintah tauhid atau mengandung makna pemurnian tauhid bagi kaum jahiliyah Arab, atau disebut surat al-Ikhlas (dalam kitab-kitab tafsir) karena dianggap sebagai surat yang berisi perintah pelepasan orang-orang mukmin dari perbuatan syirik, menyembah patung dll, wallahua'lam.

Secara rinci akan diutarakan sub-sub yang akan dianalisis dengan mengetengahkan beberapa unsur yang dapat mewakili objek kajian seperti kata "al-Kafirun", "'abid", "'abdun", dan kata "din", empat 
kata tersebut -selayang pandang- dianggap sebagai kata yang transenden lagi sakral.

Tetapi sebelumnya akan didiskripsikan secara singkat tentang makna awal yang didapatkan dalam beberapa tafsir secara umum

Pertama, kata kafir, anggapan jumhur muslimin dan mayoritas para ulama' tafsir khususnya dalam surat al-Kafirun mengenai makna kata ini adalah sebuah kata yang menyimbolkan person yang durhaka pada Allah dan menyembah kepada selain-Nya (syirik).

Kedua, kata ‘abid, menunjuk kepada seorang (person) hamba yang taat beribadah dan mengindikasikan sebatas hubungan vertikal hamba dengan Penciptanya.

Ketiga, kata 'abd, menunjuk pada aktivitas yang bersifat semata ketundukan secara vertikal, tidak menunjuk pada selain dari penjelasan diatas.

Kempat, kata Din, menunjuk kepada keyakinan yang dianut umat manusia sebagai jalan keselamatan, seperti agama Islam, Yahudi, agama Nasrani dan lain-lain.

Dimulai dengan asumsi para mufassir, dimana mereka tidak sedikitpun beranggapan bahwa kata-kata tersebut sebagai kata-kata yang men-sosial dan bersifat humanis atau menyejarah, padahal ayatayat tersebut merupakan khitab terhadap apa yang dilakukan oleh masyarakat Arab jahiliyah yang melalaikan Tuhan mereka karena kesibukan mereka dengan patung yang dibuatnya.

Apakah betul khitab kafir tersebut sebagai cap kedurhakaan atau pengingkaran mereka dengan Tuhan mereka, dengan keberadaan mereka yang menyembah patung (klaiman sebagain mereka) ataukah karena faktor ketertutupan mereka dengan lingkungan sosial mereka?.

Sebab ketika mereka melakukan ritual penyembahan patung juga termasuk ibadah, akan tetapi, hal tersebut dianggap sebagai perantara saja antara penghambaaannya terhadap patung-patung dengan Tuhan Yang Maha besar, dalam al-Qur'an dijelaskan fenomena semacam ini secara jelas, yang artinya kira-kira: "Kami tidak menyembah mereka kecuali hanya sebagai wasilah yang mendekatkan kami sedekat-dekatnya 
kepada Allah", dengan demikian bangsa Arab pada saat itu menganggap peneyembahan mereka kepada mereka hanya untuk mendekatkan diri mereka dengan Allah sekalipun mereka melalaikan Tuhan mereka karena penghambaaan mereka kepada patung, fenomena semacam ini bukan hanya terjadi pada masyrakat tertentu saja,l tetapi terjadi pada semua level masyarakat, apapbila sudah dihinggapi oleh penyakit material maka akan melupakan Tuhan mereka, coba kita renungkan ungkapan manis seorang sufi sebagai berikut:

(Seandainya tersirat dibenakku selain Engkau sedetikpun maka saya akan hukumkan diriku sama seperti orang murtad)

Ungkapan diatas menunjukkan bukan saja karena dengan menyembah patung saja kita akan dikategorikan orang kafir, tetapi tidak menghadirkan sedetikpun Tuhan dalam benak kita, maka itu juga disebut sebagai orang kafir alias murtad.

Seandainya mereka terbatas pada bentuk materialnya saja dalam keyakinan berarti mereka men-Thankan banyak tuhan, tetapi tidak sama sekali, mereka mengakui adanya Pencita tunggal yaitu Allah, sebagaimana firman Allah dalam al-Qur'an al-Karim, yang artinya: "Dan jika mereka ditanya siapa pencipta langit dan bumi, mereka pasti akan menjawab, Dialah Allah", salah seorang diantra mereka berkata kepada Muhammad sebagai penjelas dari ayat ini, dengan mengatakan: "wahai Muhammad saya mempunyai satu Tuhan yang aku bangun setiap malam karena-Nya dan selalu puasa setiap harinya, semua ini adalah sebagai bukti pengakuan mereka kepada Allah.

Jadi, tidak valid jikalau dikatakan kepada mereka kafir karena keingkarannya terhadap wujud Allah, tetapi khitab kafir di sana (dalam konteks ini) berarti ketertutupan mereka terhadap apa yang dibawa oleh Muhammad saw. berupa sunnah hasanah, yang berorientasi pada pembenahan tradisi mereka yang masih kental dengan sukuisme dan fanatisme, yang mendarah daging menjadi keyakinan dan idiologi mereka, hingga mereka tidak pernah tahu system kerjasama (cooperation) 
dalam satu wadah, akan tetapi justru terbiasa dalam paying kefanatikan, kesukuan dan sebagainya, sedangkan Muhammad datang membawa bendera hikmah, pembenahan (rekonstruksi) dan dating untuk membawa perubahan system jahiliyah yang ada, mengajak mereka dibawah kesetaraan dan panji keadilan, tidak lagi menganut corak atau identitas individual semata. Karena itulah mereka melawan dan menutup diri dengan sunnah yang baru ini, disebabkan mereka sama sekali tidak pernah mengenal system seperti ini (egalitarian, keadilan dan kebersamaan) yang tidak dibatasi oleh kesukuan dan kefanatikan mereka, tetapi saying mereka hanya tahu kebersamaan sebatas suku mereka sendiri tidak dengan yang lainnya, diskripsi ini semua menunjukkan kondisi situasional realitas dari konteks zaman itu.

Mereka tidak hanya dikhitab dengan kata kafir, mereka juga dikhitab dengan kata jahil firman Tuhan (Katakanlah apakah selain Allah kalian memerintahkan aku menyembah wahai orang-orang jahil), ini karena ketidaktahuan mereka selain hanya sikap individualisme, sukuisme dan fanatisme buta, mereka tidak tahu keberadaan orang diluar sistemnya, benarlah apa yang diungkapkan oleh Imam ar-Razi yang mengatkan: Jahil adalah ibarat sebuah pohon dan kafir adalah buahnya", oleh sebab itu dengan kebodohannya, mereka ingkar terhadap apa yang dibawa oleh Muhammad, demikianlah gambaran realitas yang berkembang pada saat ayat turun dikalngan masyarakat Arab secara umum.

Jika kita melihat keseluruhan argumentasi tersebut diatas niscaya kita dapat menemukan imformasi baru dari ungkpan Tuhan yang mengatakan: " Kul ya ayyuhal kafirun", bahwa hakikat dari khitab ini bukan berarti klaim atau dakwaan Tuhan atas pengingkaran mereka terhadap tidak adanya sang Pencipta atau tidak percaya tentang adanya Allah, tetapi khitab ini mengimformasikan kepada kita tentang ketertutupan mereka terhadap system baru yang dibawa oleh Muhammad saw.

Kalau demikian, bagaimana dengan penolakan Muhammad terhadap ajakan mereka untuk bersekutu dengannya?, jawabannya 
adalah karena nabi sendiri adalah seorang yang idak ingin tunduk dalam system jahiliyah yang masih mengagung-agungkan fanatisme, sukuisme, dan individualisme sedangkan nabi sendiri diutus untuk menghilangkan sifat-sifat tersebut, prinsip ini tercermin dalam hadistnya yang terjemahannya kira-kira sebagai berikut: "Bukan termasuk golongan umatku siappun yang mengajak kepada kefanatikan atau terbunuh karena kefanatikan". Perlu dingat juga bahwa patung-patung tersebut adalah symbol kebanggaan mereka, yang membuat jarak antara mereka yang kaya dengan mereka yang tidak mampu,. Berbeda dengan seruan nabi untuk berpayung dalam satu wadah kesetraan dan ia menggambarkannya seolah gigi sisir (Orang-orang mukmin berada sejajar seperti gigi sisir, tidak ada keutamaan antara orang Arab dengan orang ajam kecuali takwa), dan firman Allah (Sesungguhnya yang paling mulia diantara kalian adalah orang yang paling bertakwa).

Kita beralih ke ayat berikutnya (La a’budu ma ta`budun. Wa la antum abidun ma a'bud. Wa la ana abidun ma abadtum. Wa la antum abidun ma a'bud). Pengulangan atau frekuensi dari kalimat ini sesungguhnya mengisyaratkan adanya perhatian khusus untuk lebih cermat dalam memahami dengan sebaik-baiknya, akan tetapi bukan berarti semua ini memiliki satu makna, bahkan dari keseluruhan pengulangan ini menunjukkan betapa kuatnya mereka memegang prinsip, keyakinan dan tradisi nenek moyang mereka sekalipun itu memudharatkan mereka, demikin juga dengan keberadaan pribadi Muhammad dengan gigih menyuarakan kesetaraan, keadilan, dan kebersamaan diantara mereka.

Disini kita dapatkan ketidak konsistenan para ulama tafsir dalam memaknakan kata aibid atau abd, atau ada dikotomi makna secara ekstrim terhadap pemaknaan kata, satu sisi mereka (ulama' tafsir) mengartikan $t a^{\prime} b u d u n$ dengan arti menyembah kepada selain Allah atau menyembah patung, tetapi disisi lain mereka mengartikan $a^{\prime} b u d$ dengan menyembah kepada Allah, padahal kata abd sendiri dalam kamus maqayis fi al-lughah diartikan sebagai satu makna yakni menyembah hanya kepada Allah bukan menyembah kepada selain-Nya, tidak boleh mengatakan saya menyembah pulan atatu menyembah patung. 
Jadi, makna yang dimaksud adalah, seolah mengatakan: "Saya tidak menerima dan tidak rela terhadap apap yang kalian lakukan dengan kefanatikan, kesukuan dan kerasisan yang kalian perbuat, sama seperti kalian tidak akan mau menerima dan rela dengan apap yang saya lakukan sekarang berupa perbaikan, perubahan dan seruan kepada tauhid social, sebab itu tidak pernah ada bagi kalian sebelumnya.

Ayat-ayat ini merupakan gambaran dari keteguhan mereka mempertahankan tradisi mereka yang jelek, dan kegigihan Muhammmad dalam memperjuangkan kebersamaan dalam satu paying keadilan, kesetaraan dan menghilngkan rasisme diantara mereka. Dapat dikatakan sebagai gambaran lanjutan dari makna ayat pertama. Atau dapat dirumuskan sebagai berikut:

Oleh karena itu tidak sewajarnya kita mengatakan kepada mereka, bahwa mereka adalah hamba patung sedangkan nabi Muhammmad adalah hamba Allah, sebab sudah jelas duduk perkaranya dan sudah secara mendetail dijelaskan dalam firman Allah sendiri, bahwa mereka juga mengaku adanya Pencipta, maka secara ototmatis mereka juga hamba Allah, tetapi persoalan ini adalah semata persoalan sosial yang berlansung anatara mereka dengan pelaku sejarah Muhammmad saw. yang tidak terkait sama sekali dengan persoalan teologis.

Masalahnya, ada penafsiran para ulama' tafsir mengenai penolakan Muhammad terhadap penyembahan patung, apa yang dimaksud dengan statemen ini? Artinya bahwa penyembahan patung berarti penyembahan dan tunduk dalam fanatisme kesukuan dan rasisme sempit mengagungkan atau membanggakan qabilahnya sendiri, berbeda dengan risalah Muhammmad, yakni risalah manusia secara universal dalam rangka membebaskan manusia dari belenggu ketertutupan, kejumudan dan kejahiliyahan, tidak mengatasnamakan bendera hawa nafsu dan tidak mengatasnamakan satu etnis saja sebagaimana yang dilakukan oleh masyarakat jahili.

Selanjutnya kita beralih ke ayat terakhir (Lakum dinukum wa liya din), kata din disini diasumsikan oleh para penafsir konvesional sebagai 
sebuah jalan keselamatan atau tepatnya mereka menamakannya sebagai sebuah agama anutan umat manusia yang memang berasal dari wahyu Ilahi, seperti yang dianut oleh kaum muslimin disebut agama Islam, yang dianut oleh orang zionis disebut agma yahudi, sedangkan agama yang dianut oleh orang nashara disebut agama nasrani dll.

Din bisa saja diartikan sebagai peradaban, atau tradisi atau kata Ashmu `i agama adalah suatu kondisi.

Kalau kita melihat secara tektual di dalam ayat ini ada dua kata din, yang pertama termasuk susunan kalimat ma'rifat (Lakum dinukum) sedangkan kata din yang kedua merupakan susunan kalimat nakirah (Wa liya Din), menurut kebiasaan kaidah yang ada, apabila berulang-ulang makrifat maka yang pertama adalah bentuk yang kedua, jika berulangulang nakirah maka yang pertama bukan yang kedua, dan apabila makrifat diulangi dengan nakirah maka makrifat yang pertama bukan nakirah yang kedua.

Sedangkan secara kebetulan susunan ayat ini adalah seperti teori yang ketiga yaitu makrifat kemudian diulang dengan nakirah ini menandakan bahwa makna din yang pertama berbeda dengan din yang kedua. Dapat dikatakan bahwa makna din yang pertama adalah keberadaan atau kondisi objektif dan atau tradisi Arab jahili disimbolkan sebagai system sosial lama, dan makna din yang kedua merupakan bentuk kebiasaan atau sunnah baru yang dibawa oleh Muhammad saw. sebagai representasi system baru berupa perombakan tradisi lama dengan menyeru kepada islah, tajdid, dan penyempurnaan akhlak, mungkin dapat dirumuskan sebagai berikut:

Jadi, dalam hal ini makna din disini bukan seperti anggapan lama yang dianut oleh orang-orang muslim dan yang dianut oleh orangorang Yahudi dan Nasrani, sebagai sebuah agama yang berasal dari wahyu Tuhan, tetapi lebih pada sebuah sistem tradisi atau adat atau kondisi, yang satu sistem dengan sistem lainnya tidaklah sama, baik dalam standar moral, tatanan nilai, prinsip hidup serta prinsip keyakinan dll. 
Demikianlah, bagaimana proses pembacaan konteks situasional terhadap sebuah teks, dengan mengedepankan realitas objektif teks dengan menghubungkannya dengan keberadaan teks pada saat dan situasi waktu itu. Artinya pembacaan yang dilakukan dengan melihat motto atau motivasi konteks situasi yang ada tanpa melibatkan diluar realitas saat itu.

\section{Penutup}

Dengan paparan di atas, dapat disimpulkan, bahwa pembacaan konteks situasional memberikan wacana baru bagi pembacaan surat alKafirun, yang semula ini dianggap sebagai surat yang bernuansa teologis-normatif, dimana berisi sekumpulan klaim kafir karena tidak mengakui Tuhan sang Pencipta terhadap masyarakat Arab jahili, tetapi setelah dilakukan pembacaan konteks situasional, didapatkan ternyata surat ini - malah - sangat bernuansa sosiologis-humanis dan mensejarah, dimana semua konsep dalam surat adalah hasil dialektik horizontal antar sesama, bukan persoalan vertikal hamba dengan Tuhannya, kemudian terisolir menjadi masyarakat minoritas yang diklaim kafir dan tidak beragama. Jadi, term kafir, abd, 'abid, dan din tidak lebih dari sebuah tata nilai yang digunakan dalam interaksi mereka dalam kehidupan sosial, artinya ada batasan-batasan normatif sosial yang memberikan jarak diantara mereka, sehingga kalau bermunculan aturan-aturan yang bersifat ekstrim sekalipun, sudah menjadi konsekwensi dari sebuah pergumulan sosial. Dapat disistematisasikan dalam logika dibawah ini sebagai berikut:

Din adalah simbol dari wadah sosial yang didalamnya ada tradisi, budaya adat istiadat dll, sedangkan tiga ayat diatasnya yang diwakili oleh kata abd dan abid dengan segenap perangkat gramatikalnya, menunjukkan sebuah proses dialektik internal yang terjadi antara system Arab jahili dengan system baru yang dibawa oleh nabi, dimana masing-masing memiliki prinsip-prinsip dan tata nilai yang paten dan tidak bisa diganggu gugat, artinya kalau kita melihat kedua system diatas, mereka saling mempertahankan tradisi dan misi 
masing-masing, sehingga sebagai konsekwensinya muncullah term eksklusifisme atau apa yang kita kenal dengan kata kafir (ketertutupan) dalam artian tidak mau melihat realitas diluar system dirinya, tidak mau melihat perubahan, tetap berpegang dengan tradisi yang tidak berpihak pada nilai-nilai humanisme universal. Dapat dikatakan bahwa Arab jahili pada saat itu kafir (tidak mau menerima perubahan, pola pemikiran progresif, anti terhadap system baru yang mengajak kepada pembangunan perombakan sosial, penyetaraan, keadilan dan penindasan terhadap kaum lemah), sedangkan Muhammad juga kafir dalam arti tidak rela menerima sistem atau tradisi, budaya dan adat istiadat Arab jahili pada saat itu yang begitu parah, rusak dan tidak mendukung nilai-nilai humanisme universal seperti sikap fanatisme, sukuisme, tribalisme, individualisme dan sebagainya. $\square$

\section{DAFTAR PUSTAKA}

Harb, Ali. 2003 Naqd al Nash. Yogyakarta: LKiS.

2003. Al-Ta'wil Wa al-Haqiqah. Yogyakarta: LKiS.

Izutsu, Toshihiko. 1996. Ethicio Relegious Concepts in The Quran. Canada: Mc Gill Press Montreal.

Kurniawan. 2001. Semiologi Roland Barther. Magelang: Yayasan Indonesiatera.

Leech, Geoffrey. 2003 Semantics. Yogyakarta: Pustaka Pelajar.

Mardalis. 2001. Metode Penetian Suatu Pendekatan Proposal. Jakarta: PT Bumi Aksara. 
Mukhtar, Umar. 1982. Ilm al Dalalah. Kuwait: Maktabah Dar al Urubah li al Nashr wa al-tauzi'.

Nashr Hamid, Abu Zaid. 2003. Kritik Wanana Agama. Yogyakarta: LKiS.

Putra, Ashimsa. 2001. Strukturalisme Levi Strauss, Mitos dan Karya Sastra., Yogyakarta: Galang Press.

Rahardjo, Mudjia. 2002. Pengantar Penelitian Bahasa. Madang: Cendekia Paramulya.

Saenong, B. Ilham. 2002. Hermenetika Pembebasan; Metodologi Tafsir alQur'an Hasan Hanafi. Jakarta: Teraju.

Sahrur, Muhammad. 1990. Al-Kitab wa Al-Qur'an; Qiraat Muashirat. Damaskus: Al-Dimasque.

Saliba, Jamil. 1994. Mu'jam Falsafi. Beirut: Dar al Kutub al Alami. 